\title{
Pasture feeding of lambs with and without supplements in the conditions of Lapland
}

\section{LIISA SYRJÄLÄ}

Department of Animal Husbandry, University of Helsinki, SF-00710 Helsinki 71

Abstract. The need for feeding supplements to lambs on pasture was studied in 1977-1979 in northern Lapland at $69^{\circ} 40^{\prime} \mathrm{N}$ and $27^{\circ} 05^{\prime} \mathrm{E}$, where the pasture period lasts from mid June to mid September. Lambs fed on pasture alone were compared with animals whose diet was supplemented with a barley-oats meal mixture (1:1), given at the level of 400-500 g/animal/day, or large-leaved turnip (Teutoburger), offered ad libitum. The age of the lambs at the beginning of the experiments averaged three months.

The live-weight gain of the lambs receiving supplemental feeds did not differ significantly $(P<0.1)$ from that of the lambs on only pasture feeding, though the supplements tended to have a favourable effect during the second part of the pasture period, or at the beginning of August. The slaughter criteria were better, however, for the lambs receiving supplements.

Teutoburger turnip proved to be a good and palatable feed for lambs on pasture. Since it gives good yields even in northern Lapland, Teutoburger can be recommened for northerly regions where cereal crops do not ripen. The growth of lambs in Lapland seems se tifudecreasediby mosquitoes and gnats.

Introduction

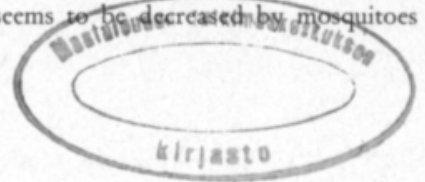

In the most important sheep husbandry countries, the feeding of sheep is based on large pasture areas, and the sheep are left out on pasture nearly all the year round. In Finland the climatic conditions restrict the pasture period to 3-5 months.

Such conditions greatly decrease the economic feasibility of raising lambs on pasture, especially in Lapland, a region lying at the limit of crop cultivation. Special attention has to be paid to the productivity of the pasture, grazing techniques and supplemental feeding. The production of lamb meat on pasture feeding alone can rarely compete with that based on high-concentrate feeding. However, if the aim is to depend entirely on local resources, grazing is almost the only possibility in areas where grain production is not successful.

The purpose of this study was to investigate the growth of lambs on pasture in the conditions of northern Lapland. The experiments were made in 1977-79 at Muddusjärvi experimental farm, owned by the University of Helsinki. This farm is one of the world's most northerly agricultural stations, being situated in Inari commune at $69^{\circ} 40^{\prime} \mathrm{N}$ and $27^{\circ} 05^{\prime} \mathrm{E}$. In that area, the growing period, or the period when the average daily temperatures are permanently over $+5^{\circ} \mathrm{C}$, lasts 
approximately 125 days (in Helsinki 175 days). In summer the sun does not set for 64 days, the time of continual light lasting from 22 May until 24 July. The pasture period is usually the time from the middle of June to the middle of September.

\section{Materials and methods}

Animals and feeding

The lambs were born in March-April and their age at the beginning of the experiments averaged three months. In 1977 the experiment comprised 34 lambs, in 197847 lambs and in 197922 lambs. In 1979 only female lambs were used (SYRJÄLÄ 1981a), and the male and female lambs used in 1978 and 1979 were kept separate. All the lambs were finnsheep. They were weaned from their mothers and put out to pasture in the middle of June. The experimental periods started one or two weeks later and lasted until the end of the grazing season. The periods were about 10-12 weeks, as follows:

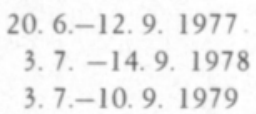

Before the beginning of the experiments the lambs were divided into two groups with similar distributions by sex, parents, age and weight: a pasture group and a concentrate group. In the pasture group the animals were raised throughout the experiment on pasture grass alone. In the concentrate group they received supplemental feed. During the first part of the experiment in 1977 the feed consisted of a grain concentrate mixture (barley-oats meal mixture 1:1), offered at the average rate of $500 \mathrm{~g} / \mathrm{animal} / \mathrm{day}$, and in the second part of the experiment large-leaved turnip (Teutoburger) was given ad libitum. In 1978 and 1979 the same barley-oats meal mixture was given as supplemental feed throughout the experiment, at the average rate of $400 \mathrm{~g} / \mathrm{animal} / \mathrm{day}$. The concentrates were offered twice a day.

A mineral mixture was available to all the animals in the form of licking stone. It consisted mainly of $\mathrm{NaCl}$, with small amounts of $\mathrm{Mg}, \mathrm{Mn}, \mathrm{Zn}, \mathrm{Cu}, \mathrm{Co}$ and $\mathrm{J}$.

The lambs were weighed every second week.

\section{Pastures}

The pasture for the lambs was planted with a seed mixture in which timothy predominated. A basic fertilizing mixture was applied in spring, to give the rates of $90 \mathrm{~kg} \mathrm{P}, 90 \mathrm{~kg} \mathrm{~K}$ and $90 \mathrm{~kg} \mathrm{~N}$ per hectare, and later in summer at the rate of $70 \mathrm{~kg}$ N.

The total pasture area ranged from 2 to 3 ha in the different years and it was divided with net or electric fences into eight blocks, four for each experimental group. Not all the blocks were used for grazing, however, the surplus grass in some blocks was cut for silage or hay.

During grazing the blocks were changed 2-3 times a month. Before the lambs were put on a new block, grass samples were taken from this block to measure the 
yield, chemical composition and feeding value of the pasture (ERIKSSON et al. 1972, SYRJÄLÄ 1972, 1975,SYRJÄLÄ et al. 1978).

\section{Results}

Feeding value of the pastures

The chemical composition and nutritive value of the pasture grass was good during all the experiments (Table 1). The crude protein content was more than $20 \%$ and the crude fibre content less than $25 \%$ of the dry matter. The dry matter content varied, however. In most samples it was about $20 \%$, but it sometimes decreased to about 16\%, especially towards the end of August. In 1979 it was also as low as this at the beginning of July.

The in vitro digestibility of the organic matter was about $70 \%$ at the beginning of the experiments, but had decreased to $60 \%$ by the end of the experiments. This decrease was clearest in 1979.

The total yields from the pasture were high, over 3000 f.u./ha. In some cases this value is based on both the grass used for grazing and the grass used for silage and hay.

\section{Live-weight gain}

There were no significant differences in the growth of the lambs between the pasture and concentrate groups $(\mathrm{P}>0.1)$. In 1977 the daily live-weight gain of the animals in both groups was best at the end of June; in the pasture group it averaged $286 \mathrm{~g} /$ animal and in the concentrate group $221 \mathrm{~g}$ (Fig. 1). The average daily live-weight gain for the whole experiment in 1977 was exactly the same in the two groups, $135-136 \mathrm{~g} / \mathrm{animal}$.

Table 1 The mean chemical composition and nutritive value of the pasture grass in differet years.

\begin{tabular}{|c|c|c|c|}
\hline & 1977 & 1978 & 1979 \\
\hline Dry matter $\ldots \ldots \ldots \ldots \ldots \ldots \ldots$ & 21.9 & 19.1 & 17.7 \\
\hline \multicolumn{4}{|l|}{$\%$ of dry matter: } \\
\hline Ash $\ldots \ldots \ldots$. & 7.7 & 8.2 & 8.7 \\
\hline Organic matter $\ldots \ldots \ldots \ldots$ & 92.3 & 91.8 & 91.3 \\
\hline Crude protein $\ldots \ldots \ldots \ldots \ldots$ & 21.5 & 20.4 & 21.1 \\
\hline Crude fat $\ldots \ldots \ldots \ldots \ldots \ldots$ & 3.7 & 4.2 & 4.2 \\
\hline $\mathrm{N}$-free extract $\ldots \ldots \ldots \ldots$ & 44.1 & 42.3 & 42.0 \\
\hline Crude fibre $\ldots \ldots \ldots \ldots \ldots$ & 23.0 & 24.9 & 24.0 \\
\hline $\mathrm{kg} / \mathrm{f} . \mathrm{u}^{\prime} \quad \ldots \ldots \ldots \ldots \ldots \ldots \ldots \ldots$ & 5.4 & 6.6 & 6.0 \\
\hline $\mathrm{DM} \mathrm{kg} / \mathrm{f} . \mathrm{u}^{2} \quad \ldots \ldots \ldots \ldots \ldots$ & 1.19 & 1.21 & 1.21 \\
\hline $\mathrm{DCP}_{\mathrm{g} / \mathrm{f} \cdot \mathrm{u}^{3} \ldots \ldots}$ & 189 & 184 & 189 \\
\hline $\mathrm{DCP} \%$ in $\mathrm{DM} \quad \ldots \ldots \ldots \ldots$ & 15.8 & 15.6 & 15.4 \\
\hline Digestibility of $\mathrm{OM}^{4} \ldots \ldots \ldots \ldots$ & & 66.6 & 63.8 \\
\hline
\end{tabular}

1 I feed unit (f.u.) $=0.7$ starch unit

$2 \mathrm{DM}=$ dry matter

${ }^{3}$ DCP $=$ digestible crude protein

${ }^{4} \mathrm{OM}=$ organic matter 
In 1978 the lambs in the concentrate group grew a little better, especially after July, than those in the pasture group (Fig. 2), but the difference was not significant $(\mathrm{P}>0.1)$. The average daily live-weight gains for the whole experiment in 1978 were $112 \mathrm{~g} /$ animal in the pasture group and $135 \mathrm{~g}$ in the concentrate group. In 1979 , on the other hand, the average growth was better in the pasture group than in the concentrate group, though not significantly so $(\mathrm{P}>0.1)$, the respective daily gains being 129 and $119 \mathrm{~g} /$ animal (Fig. 3).

\section{Slaughter results}

Slaughter results are available for only 41 lambs in 1978 and 16 in 1979. There were some differences in the criteria between the groups (Table 2). The carcass percentage of the lambs in the concentrate group in 1978 was $38 \%$ and differed significantly $(\mathrm{P}<0.1)$ from that in the pasture group, which was $35 \%$. In
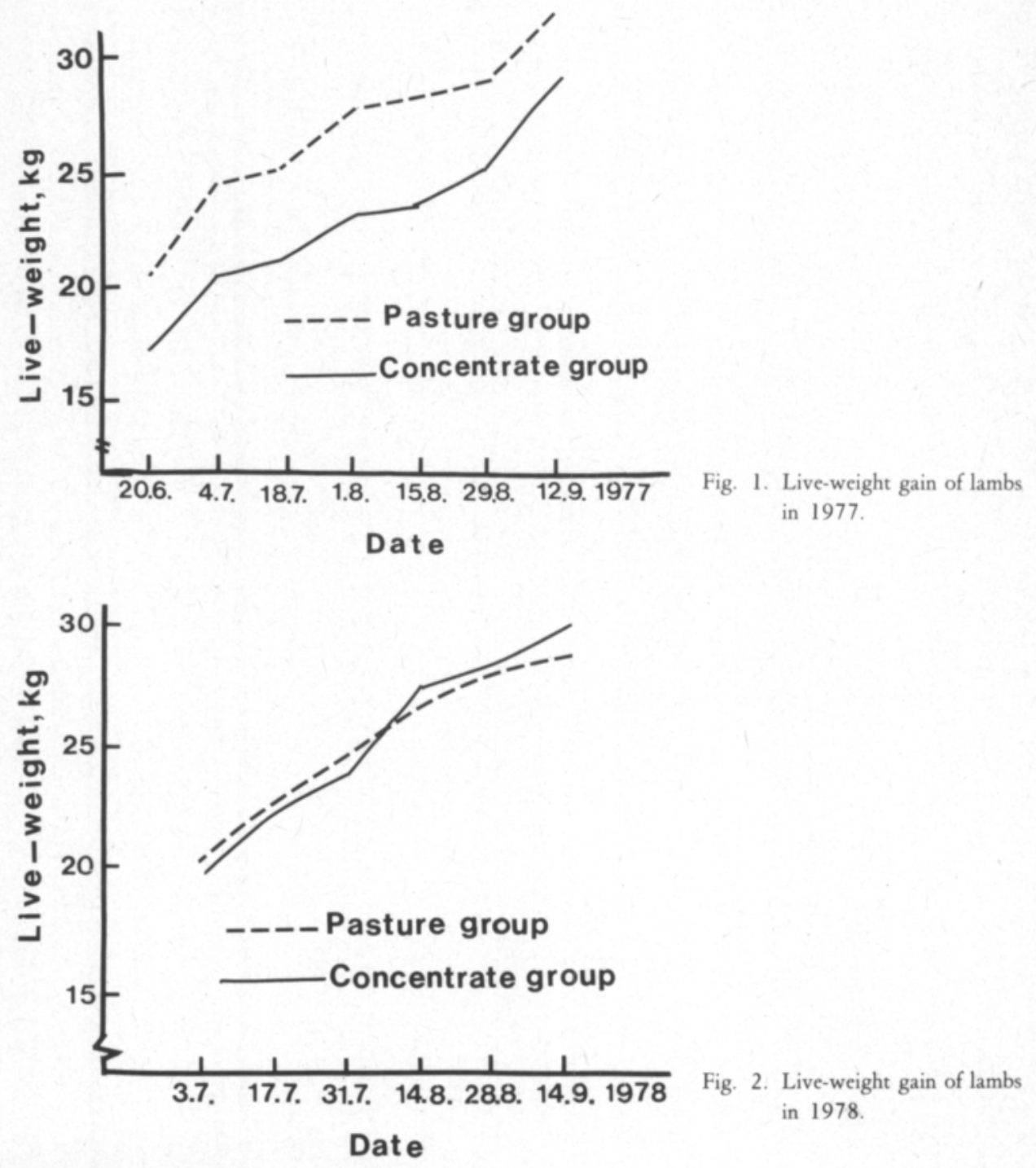

Fig. 2. Live-weight gain of lambs in 1978 . 


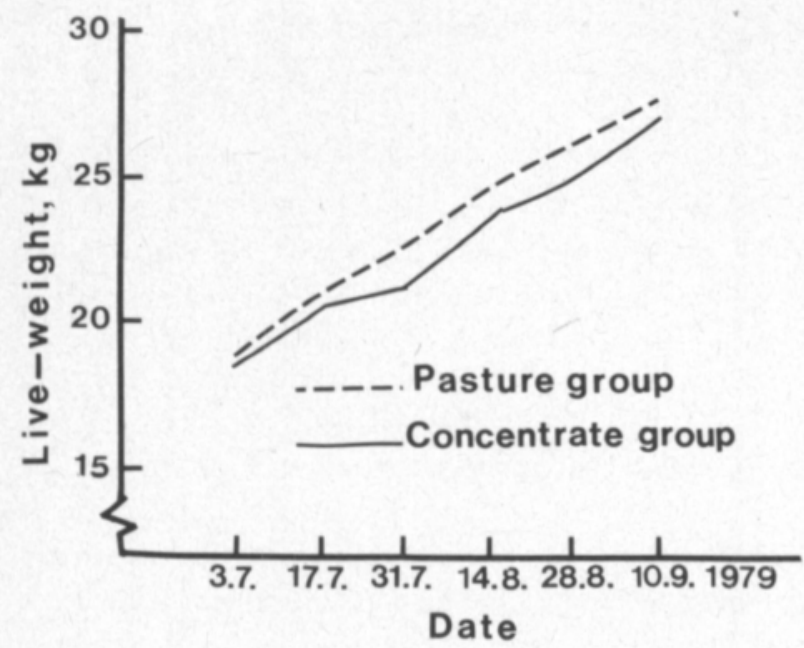

Fig. 3. Live-weight gain of female lambs in 1979.

1979 this value was the same in the two groups, about $36 \%$. The carcasses had more lean meat in the concentrate group than in the pasture group, in which the lambs were somewhat thinner. The amount of fat was also fairly good in the concentrate groups, whereas in the pasture groups it was poor.

\section{Discussion}

The live-weight gains of the lambs were rather small, in spite of the the fact that the pastures were fairly good throughout the experiments and the grazing density was not very high, generally 15-20 lambs/ha. In experiment made in central Finland (SORMUNEN 1979) better growth was obtained at a grazing density of 17 lambs/ha than of 25 or $33 \mathrm{lambs} / \mathrm{ha}$.

The barley-oats mixture used in these experiments contained $1.1 \mathrm{f} . \mathrm{u} . / \mathrm{kg}$ and 86 $\mathrm{g}$ DCP/f.u. In the concentrate groups the lambs daily received about $0.4 \mathrm{f}$.u. and 32-40 g DCP from this mixture. These values represent about half of their energy

Table 2. Slaughter results.

\begin{tabular}{|c|c|c|c|c|}
\hline & \multicolumn{2}{|c|}{1978} & \multicolumn{2}{|c|}{1979} \\
\hline & $\begin{array}{l}\text { Pasture } \\
\text { group }\end{array}$ & $\begin{array}{l}\text { Concentrate } \\
\text { group }\end{array}$ & $\begin{array}{l}\text { Pasture } \\
\text { group }\end{array}$ & $\begin{array}{c}\text { Concentrate } \\
\text { group }\end{array}$ \\
\hline Live weight, $\mathrm{kg}$ & 28.4 & 29.2 & 26.7 & 26.1 \\
\hline Carcass weight, $\mathrm{kg} \quad \ldots \ldots \ldots \ldots \ldots \ldots$ & 9.9 & 11.0 & 9.6 & 9.6 \\
\hline Dressing $\% \ldots \ldots \ldots \ldots \ldots \ldots \ldots$ & 35 & 38 & 36 & 36 \\
\hline $\begin{array}{l}\text { Quality points }(10-20) \ldots \ldots \ldots \ldots \ldots \\
\text { (poor-excellent) }\end{array}$ & 12.7 & 13.3 & 14.6 & 14.0 \\
\hline Qyality class, $\%$ of lambs & & & & \\
\hline I (good) $\ldots$ & 18 & 47 & 86 & 67 \\
\hline II (medium) $\ldots \ldots \ldots \ldots \ldots$ & 77 & 47 & 4 & 33 \\
\hline III (poor) $\ldots \ldots \ldots \ldots \ldots \ldots$ & 5 & 6 & 0 & 0 \\
\hline Fatness of carcass, $\%$ of lambs & & & & \\
\hline $\mathrm{T}$ (fat-free) $\ldots \ldots \ldots \ldots \ldots$ & 91 & 53 & 100 & 5s \\
\hline A (thin fat cover) $\ldots \ldots \ldots \ldots$ & 9 & 47 & 0 & 45 \\
\hline
\end{tabular}


requirements and one third of their protein requirements, if the requirements of lambs at $20-30 \mathrm{~kg}$ live-weight and at daily growth rate of $200 \mathrm{~g}$ are assumed to be 0.76 f.u. and $99 \mathrm{~g} \mathrm{DCP}$ per day (ANON 1978).

Large amounts of concentrate have been shown to decrease the utilization of pasture, especially when the grazing density is low (NEWTON and YOUNG 1974). The intake of pasture grass decreased linearly, as the amount of concentrate increased (ALLDEN 1969). A daily concentrate ration of $100 \mathrm{~g}$ diminished the intake of pasture grass by $8 \%$ (MARTINSON 1979). In contrast to these results in some other experiments the lambs clearly grew better if concentrate was fed as a supplement to the pasture (LARGE and SPEDDING 1964, ANTILA 1976). Supplemental feeding is necessary when the grazing density is high or in late summer, when the nutrient requirements of the lambs increase, and the production of pasture herbage slows down (STEEN et al. 1972). It is also possible that the low dry matter content of the pasture grass decreases the intake and thus reduces the energy supply from the pasture. The dry matter of some pasture samples in the present experiments was as low as $16 \%$.

Teutoburger turnip was roughly equivalent to grain concentrate as a supplement to pasture. It also proved to be very palatable, gaining the highest possible points in the palatability test (SYRJÄLÄ 1981b). The yields of this large-leaved turnip in Lapland conditions were fairly good, about 7-8 tons of dry matter per hectare. Since it is available for feeding just at the time when a supplement to pasture is needed, or from the middle of August, it can be strongly recommended in Lapland, when the aim is to depend solely on local resources. Cereal crops do not ripen in northern Lapland, and grain has to be brought up from the more southern parts of Finland.

The low growth rates of the lambs can also be caused by mosquitoes and gnats, which occur in great number at a certain time in Lapland. During the worst mosquito period, the lambs are restless and keep moving all the time. In a preliminary test arranged during that period, lambs treated daily with mosquito oil or spray continued to grow normally, whereas untreated lambs stopped growing (SYRJÄJÄ 1981c). All the lambs were healthy during the present experiments, and no diarrhea was observed.

Acknowledgements. - I wish to express my best thanks to Mrs. Aulikki Moisio and Mr. Kyösti Mãenpää and all the students in Muddusniemi for technical help.

\section{References}

ALLDEN, W. G. 1969. The summer nutrition of weaned sheep. Austr. J. Agric. Res. 20: 499-512.

ANON. 1978. Lammastalous. Ruokinta ja rehunkulutuslaskelmia. Maatalouskeskusten liitto 1/78. Helsinki. ANTILA, U. 1976. Väkirehuvaltainen ruokinta ja laidunruokinta karitsoiden kasvatuksessa. Lammastalous 1: 6-11, 2: 4-8.

ERIKSSON, S., SANNE, S., \& THOMKE, S. 1972. Fodermedelstabeller och utfodringnormer. 48 p. Borås. LARGE, R. V. \& SPEDDING, C. R. W. 1964. The growth of lambs at pasture. Grassl. Res. Inst. T. C. 391. MARTINSSON, K. 1976. Lammens foderförsorjning på bete. Fårskötsel 6: 9, 7: 5-7.

NEWTON, J. E. \& YOUNG, N. E. 1974. The performance and intake of weaned lambs grazing S 24 perennial ryegrass with and without supplementation. Anim. Prod. 18: 191-199. 
SORMUNEN, R. 1979. Karitsoiden kasvatus laitumella. MTTK Kotieläinhoidon tutkimuslaitoksen kokeita. STEEN, E., MATSON, C. \& SVENSSON, C. 1972. Landskapsvård med betesdjur. Akt. från lantbr. högsk. 182. Uppsala.

SYRJÄLÄ, L. 1972. Effect of different sucrose, starch and cellulose supplements on the utilization of grass silages by ruminants. Ann. Agric. Fenn. 11: 199-276.

- 1975. Live-weight gain, feed intake and wool growth of lambs on different grass silages and sucrose and starch supplements. Ann. Agric. Fenn. 14: 338-348.

- 1981a. Rasing lambs on natural and cultivated pastures in the conditions of Lapland. J. Scient. Agric. Soc. Finl. 53: 146-151.

- 1981b. Vihantarehukasvien maittavuus. (In press.)

- 1981c. Lammastutkimusta Lapissa. Hyttyset lampaiden riesana. Lammastalous 2: 14-16.

- , SUVITIE, M. \& SEPPÄLÄ, J. 1978. Timoteinurmen sato, koostumus ja sulavuus kasvukauden eri aikoina. Kehittyvä Maat. 39: 27-35.

Ms received May 22, 1981.

\section{SELOSTUS}

\section{Lisärehun tarve karitsoiden laidunruokinnassa Lapin olosuhteissa}

\section{Liisa Syrjälä}

Helsingin yliopiston kotieläintieteen laitos, 00710 Helsinki 71

Helsingin yliopiston omistamalla Muddusniemen Tutkimusasemalla (nyk. Muddusjärven opetus- ja koetila) Inarissa selvitettiin vuosina 1977-79 lisärehun tarvetta karitsoiden laidunruokinnassa. Kunakin vuonna oli kokeessa kaksi ryhmää: 1) Laidunryhmä, joka oli koko koekauden pelkällä laidunruoholla ja 2) Lisärehuryhmä, joka sai laitumelle lisärehuna viljaväkirehua (ohra-kauraseso $1: 1$ ) $400-500 \mathrm{~g} / \mathrm{eläin} / \mathrm{pv}$ tai naattinaurista (Teutoburger). - Laidun oli timoteivaltaista nurmea ja laiduntamistiheys $15-20 \mathrm{karitsaa} / \mathrm{ha}$.

Vuonna 1977 oli kokeessa 34 karitsaa, vuonna 197847 karitsaa ja vuonna 197922 uuhikaritsaa. Kokeet aloitettiin kesäkuun loppupuolella tai heinäkuun alussa ja lopetettiin syyskuun puolivälissä. Karitsoiden ikä kokeiden alkaessa oli keskimäärin kolme kuukautta.

Laidun- ja lisärehuryhmien karitsoiden kasvussa ei ollut merkitseviä eroja. Vastaavat keskimääräiset päivittäiset kasvut koko kokeen aikana olivat seuraavat: v. 1977135 ja 136 g, v. 1978112 ja 135 g, v. 1979 129 ja $119 \mathrm{~g}$. Teurastulokset sensijaan olivat lisärehuryhmien karitsoilla paremmat kuin laidunryhmien karitsoilla. Teurasprosentti oli v. 1978 laidunryhmällä 35 ja lisärehuryhmällä 38. V. 1979 se oli molemmilla ryhmillä 36. - Sääsket ja mäkäräiset heikensivät karitsoiden kasvua.

Tutkimustulokset osoittivat, että kesä- ja heinäkuun aikana lisärehu on tarpeetonta, jos laitumet ovat hyvässã kunnossa. Elokuun alkupuolelta lähtien lisärehu sensijaan parantaa kasvu- ja teurastuloksia. Naattinauris osoittautui maittavaksi sekã satoisaksi lisärehuksi Pohjois-Lapin olosuhteissa. 